\title{
Upaya Meningkatkan Kemampuan Pemahaman Konsep Trigonometri Melalui Pendekatan Konstruktivisme dengan Berbantukan Macromedia Flash 8 Pada Mahasiswa Program Studi Pendidikan Matematika FKIP Universitas Bengkulu
}

\author{
Effie Efrida Muchlis ${ }^{1}$, Syafdi Maizora ${ }^{2}$ \\ Program Studi Pendidikan Matematika JPMIPA FKIP Universitas Bengkulu \\ effie efrida@yahoo.com \\ Program Studi Pendidikan Matematika JPMIPA FKIP Universitas Bengkulu \\ Syafdiichiemaizora@yahoo.com
}

\begin{abstract}
Abstrak
Penelitian ini bertujuan untuk 1) Meningkatkan aktifitas mahasiswa Program studi pendidikan matematika dalam pembelajaran trigonometri dengan pendekatan konstruktivisme yang berbantukan macromedia flash 8. 2) Meningkatkan kemampuan pemahaman konsep mahasiswa dalam pembelajaran trigonometri dengan pendekatan konstruktivisme yang berbantukan macromedia flash 8. Jenis penelitian ini merupakan penelitian Tindakan Kelas. Subjek penelitian adalah mahasiswa Progaram Studi Pendidikan Matematika yang mengambil mata kuliah trigonometri pada tahun akademik 2014/2015. Instrumen yang digunakan adalah soal tes pemahaman konsep, lembar observasi aktivitas mahasiswa dan dokumentasi. Hasil penelitian menunjukkan 1) untuk meningkatkan aktifitas mahasiswa dalam pembelajaran trigonometri dengan pendekatan konstruktivisme yang berbantukan macromedia flash 8, dilakukan dengna cara : a) Mahasiswa dibagi ke dalam beberapa kelompok yang heterogen. b) Meminta mahasiswa mengemukakan gagasan terhadap materi yang akan dipelajari. c) Memberi kesempatan kepada mahasiswa untuk melakukan diskusi kelas. d) Meminta mahasiswa menyiapkan diri untuk mempelajari materi yang akan dibahas pada pertemuan berikutnya di rumah. 2) Penerapan pendekatan konstruktivisme dengan bantuan macromedia flash 8 dapat meningkatkan pemahaman konsep mahasiswa, yaitu dari nilai rata-rata 68,05 dengan ketuntasan belajar secara klasikal 53,13\% pada siklus 1 dan pada siklus 2 nilai rata-rata 71,69 dengan ketuntasan belajar secara klasikal 76,36\% serta pada siklus 3 nilai rata-rata 82,45 dengan ketuntasan belajar secara klasikal 89,09\%.
\end{abstract}

Kata kunci : macromedia flash 8, pemahaman konsep, pendekatan konstruktivis.

\section{PENDAHULUAN}

Mata kuliah trigonometri didasari pada penguasaan konsep dasar yang menuntut lebih kepada mahasiswa untuk mengembangkan penalarannya dalam memahami fakta yang terdapat pada konsep trigonometri. Penguasaan konsep dasar tentang trigonometri ini penting karena merupakan konsep dasar yang harus dimiliki mahasiswa untuk menguasai bahasan lain yang dibicarakan pada rincian materi trigonometri pada pertemuan berikutnya, yang tentu saja membutuhkan konsep dasar yang benar. Mahasiswa dan dosen merupakan dua komponen yang saling kait mengait. Peran dosen dalam proses pembelajaran adalah sebagai motivator, fasilitator, evaluator dan tentu saja sebagai salah satu sumber belajar. Oleh karenanya untuk meningkatkan keefektifan proses dan hasil pembelajaran trigonometri antara lain tidak hanya dilakukan perbaikan pada diri dosen akan tetapi juga tidak kalah pentingnya dan menentukan adalah perbaikan pada diri mahasiswa sendiri. Dengan demikian untuk mengatasi masalah-masalah yang timbul dalam pembelajaran trigonometri ini dilakukan perbaikan yang meliputi pendekatan yang digunakan, media yang digunakan, dan evaluasi yang dilakukan.

Salah satu bentuk pendekatan dalam pembelajaran adalah pendekatan konstruktivisme yang didasarkan pada pendapat piage (dalam Panen, 2005) menyatakan bahwa "proses belajar diawali denga terjadinya konflik kognitif, sehingga pada akhir proses pembelajran siswa akan membangun sendiri pengetahuan melalui interaksi dengan lingkungan".Dalam mengembangkan model pembelajaran konstruktivisme para dosen hendaknya :

1. Mengetahui dan mempertimbangkan pengetahuan awal siswa.

2. Memperlihatkan interaksi sosial dengan melibatkan siswa dalam diskusi kelas atau kelompok.

3. Memandang pembelajran sebagai proses perubahan konsepsi pada siswa.

Konstruktivisme pembelajaran adalah upaya mengintegrasikan pengetahuan (gagasan) personal siswa dengan pengetahuan sekolah (kurikulum). Gagasan siswa merupakan pengetahuan pribadi mereka, yaitu gagasan terbentuk melalui belajar yang informal dalam proses yang memahami pengalaman sehari-hari. Metode yang digunakan akan menjadi baik apabila dalam pelaksanaan pembelajarannya dosen menggunakan 
bantuan media pembelajaran yang memafaatkan soft ware Macromedia Flash 8. Karena dengan menggunakan media yang berbantukan macromedia flash 8 dapat mempermudah dosen dalam memvisualisasikan simulasi dan animasi sehingga membuat gambar seperti hidup. Selain itu, Macromedia Flash 8 juga memungkinkan untuk membuat movie interaktif dimana user dapat menggunakan keyboard atau mouse untuk melakukan interaksi. Pembelajaran dengan bantuaan Macromedia Flash 8 ini diharapkan akan dapat memotivasi siswa untuk belajar, karena dapat menampilkan penyajian materi secara menarik dan informatif. mahasiswa menjadi mudah memahami suatu materi karena memberi gambaran dan informasi yang lebih nyata dan jelas. Selain itu dapat memperbesar minat dan motivasi siswa untuk belajar (Djamarah, 2002: 155).

Hiebert dan Lavefre (dalam Van de Wall, 2008) menyebutkan "pengetahuan konsep adalah pengetahuan yang berisi banyak hubungan atau jaringan ide". Berdasarkan pengertian tersebut pengetahuan konsep lebih dari sekedar ide tunggal karena kita bisa menggunakan ide yang kita miliki untuk menemukan ide baru dan mengembnagkan hubungan antar ide. Menurut Kilpatrick (dalam Widjajanti, 2011) menyatakan "pemahaman konseptual (conseptual Understanding) adalah pemahaman atau penguasaan mahasiswa terhadap konsep-konsep, operasi dan relasi matematis". Indikator yang dapat digunakan untuk mengetahui pemahaman konseptual antara lain adalah mahasiswa mampu:

1. Menyatakan ulang konsep yang telah dipelajari.

2. Mengklasifikasikan objek-objek berdasarkan dipenuhi tidaknya persyaratan membentuk konsep tersebut.

3. Memberi contoh dan noncontoh dari konsep yang dipelajari.

4. Menyajikan konsep dalam berbagai macam bentuk representasi matematis

5. Mengaitkan berbagai konsep.

Penelitian yang dilakukan oleh Mike, Mukhni, Irwan (2012) dengan judul pemahaman konsep matematika pada materi turunan dengan teknik probing. Indikator pemahaman konsep yang digunakan dalam adalah menyatakan ulang sebuah konsep, mengklasifikasikan objek menurut sifat-sifat tertentu, dan mengaplikasikan konsep atau algoritma ke dalam pemecahan. Hasil penelitian Menunjukkan bahwa pembelajaran dengan menggunakan teknik probing dapat meningkatkan pemahaman konsep matematika dibandingkan dengan pembelajaran dengan konvensional.

Penelitian yang dilakukan oleh Aprilianto (2012) dengan judul meningkatkan pemehaman konsep dan strategis matematis siswa SMP dengan pendekatan Methaporital thinking. Hasil penelitian menunjukkan (1) Terdapat perbedaan peningkatan pemahaman konsep dan kompetensi strategis matematis antara siswa yang memperoleh pembelajaran dengan pendekatan metaphorical thinking, dengan siswa yang memperoleh pembelajaran biasa; (2) Siswa menunjukkan sikap yang positif terhadap pembelajaran dengan pendekatan metaphorical thinking.

\section{METODE PENELITIAN}

Penelitian yang dilakukan adalah Penelitian Tindakan Kelas (Classroom Action Research) yang dilaksanakan dalam tiga siklus. Dalam setiap siklus terdiri dari langkah-langkah : perencanaan, pelaksanaan, observasi, refleksi. Subjek dalam penelitian ini mahasiswa Progaram Studi Pendidikan Matematika yang mengambil mata kuliah trigonometri pada tahun akademik 2014/2015. Objek dalam penelitian ini adalah pendekatan yang digunakan yaitu pendekatan konstruktivisme dengan bantuan macromedia flash 8 dalam pembelajaran mata kuliah trigonometri. Pengumpulan data dalam penelitian ini menggunakan instrumen berupa lembar observasi, tes pemahaman konsep dan dokumentasi. Adapun tes yang dilakukan dalam penelitian ini adalah tes tertulis dengan bentuk soal adalah essay yaitu pre-tes dan post-tes. Pre-tes diadakan pada awal kegiatan belajar yang berguna untuk melihat sampai sejauh mana kesiapan mahasiswa dalam menerima materi kuliah yang akan disajikan. Selanjutnya pada akhir materi perkuliahan (kegiatan bekajar mengajar) di adakan pos-tes untuk melihat sejauh mana mahasiswa telah menguasai materi yang diajarkan dengan pendekatan konstruktivisme yang berbatukan macromedia flash 8. Data yang diperoleh dianalisis secara deskriptif. Observasi dilakukan dengan mengamati proses yang terjadi selama proses pembelajaran berlangsung yang telah dilengkapi dengan lembar observasi untuk mahasiswa. Untuk mengamati keaktifan individu maupun keaktifan kelompok dilakukan pada saat siswa melakukan diskusi dan ketika menyelasaikan masalah atau soal-soal yang telah diberikan oleh dosen. Terhadap mahasiswa hal-hal yang perlu diamati adalah: mahasiswa yang aktif, mahasiswa yang pasif, mahasiswa yang cenderung berbuat individual dan kerja sama mahasiswa dalam menyelesaikan soal.adapun indikator keberhasilan tindakan penelitian ini adalah:

1. Kemampuan Pemahaman konsep

a. Mahasiswa mampu menyatakan ulang konsep yang telah dipelajari

b. Mahasiswa mampu memberi contoh dan noncontoh dari konsep yang dipelajari. 
c. Mahasiswa mampu menyajikan konsep dalam berbagai macam bentuk representasi matematis

2. Hasil belajar

Hasil belajar mahasiswa setelah diberi post tes yang mendapat nilai $\geq 65$ sebanyak $85 \%$

\section{EKSPERIMEN DAN PEMBAHASAN}

Pada penelitian ini penerapan pendekatan konstruktivisme dengan bantuan macromedia flash 8 pada mata kuliah trigonometri dilaksanakan selama 3 siklus. Dalam pelaksanaan pembelajaran mata kuliah trigonometri pada siklus 1 yang menerapkan pendekatan konstruktivisme dengan bantuan macromedia flash 8, mahasiswa dibagi ke dalam delapan kelompok yang terdiri dari enam sampai delapan orang berdasarkan hasil tes kemampuan dasar. Dosen memulai perkuliahan dengan menjelaskan materi dasar yaitu meteri mengenai perbandingan trigonometri pada kwadran I. Materi ini merupakan materi dasar yang dapat digunakan mahasiswa untuk memahami materi perbandingan trigonometri pada kwadran II, kwdran III, dan kwadran IV melalui materi ini mahasiswa dapat menemukan ide atau gagasan baru. Materi dijelaskan dengan berbatukan macromedia flash 8 , karena dengan menggunakan macromedia flash 8 dapat dibuat gambar yang memiliki animasi. Setelah materi dasar dijelaskan, dosen meminta agar setiap kelompok mengerjakan LKS yang dirancang agar mahasiswa dapat melakukan konstruktivisme yaitu dapat menggunakan konsep dasar yang telah dimiliki untuk menemukan gagasan baru.

Kegiatan konstruktivisme yang dilakukan oleh mahasiswa adalah pada saat membuktikan nilai cos $60^{0}=1 / 2$. Mahasiswa menggunakan definisi perbandingan trigonometri dan teorema phytagoras untuk membuktikan bahwa nilai dari $\cos 60^{\circ}$ adalah $1 / 2$. Berikut contoh jawaban mahasiswa dalam membuktikan bahwa $\cos 60^{\circ}=1 / 2$, dapat dilihat pada Gambar 3.1 berikut.

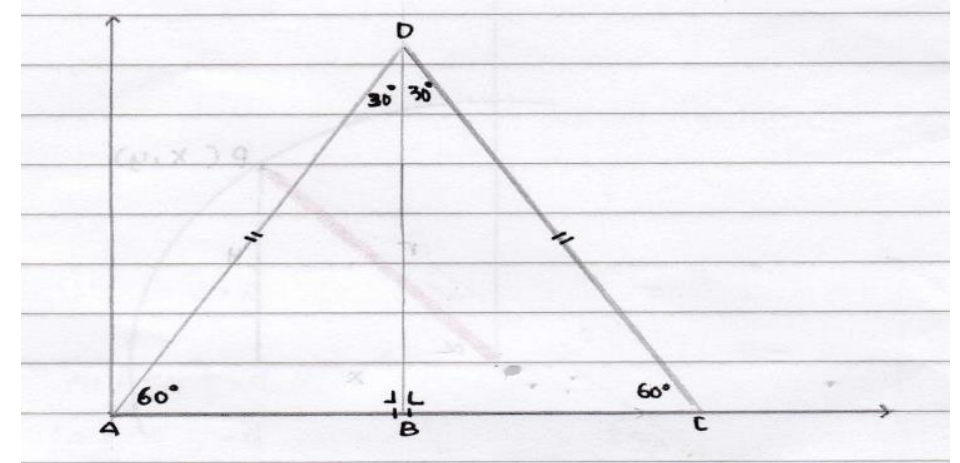

\section{Gambar 1. Pengunaan Konsep Segitiga Sama sisi untuk menemukan nilai cos 60}

Konsep dasar yang digunakan mahasiswa untukmennetukan nilai cos $60^{\circ}$ adalah dengan menggambarkan segitiga sama sisi. Kemudian mahasiswa memulai dengan menggunakan jumlah sudut yang terdapat pada segitiga sama sisi. Dengan membentuk garis tinggi dari sudut D ke sisi alas segitiga sama sisi, maka mahasiswa mulai menentuka harga cos $60^{\circ}$. Konsep dasar yang dimiliki mahasiswa dapat membantu mahasiswa untuk mengkonstruksi pengetahuan baru. Langkah berikutnya adalah mahasiswa membentuk gambar dan melakukan analisi, seperti yang terlihat pada Gambar 2 berikut:

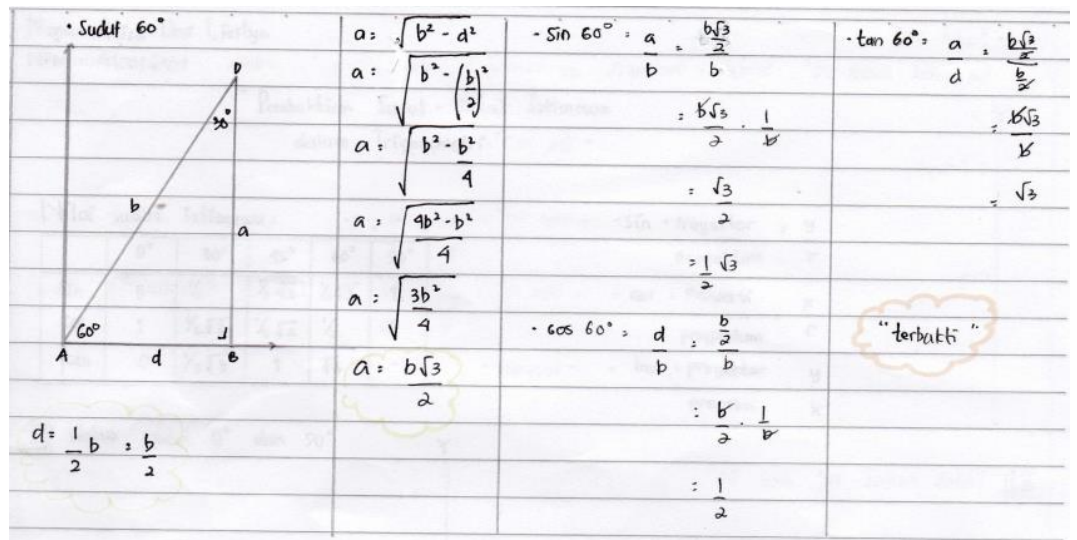

Gambar 2. Jawaban siswa dalam menentukan nilai dari $\cos 60^{\circ}$ 
Jawaban yang diberikan oleh mahasiswa ini menunjukkan kemmapuan mahasiswa untuk menyatakan ulang suatu konsep. Dapat menunjukkan nilai dari $\cos 60^{\circ}$ adalah $1 / 2$, dengan kembali menunjukkan defini dari $\cos \alpha$ sekaligus menggunkan konsep tersebut sebagai konsep dasar dalam menunjukkan nilai dari $\cos 60^{0}$ adalah $1 / 2$.

Pada siklus 1 kerjasama mahasiswa dalam satu kelompok dalam menyelesaikan tugas yang diberikan dosen masih kurang. Hal ini dapat diamati dari mahasiswa yang kurang menguasai tugas yang telah dibuat kelompoknya dan belum siap untuk sendiri membahas materi pada kegiatan pembelajaran. Kemampuan mahasiswa dalam memahami konsep juga masih kurang terlihat dari hasil tes siklus 1, masih sedikit mahasiswa yang dapat menyatakan ulang suatu konsep dan masih banyak mahasiswa yang belum dapat menyajikan masalah dalam berbagai bentuk representasi. Masih ada sebagian mahasiswa belum aktif, belum dapat berdiskusi dengan baik, belum dapat menjawab pertanyaan dosen dan tidak memperhatikan penjelasan teman ini terlihat dengan jika sembarang mahasiswa yang ditunjuk dalam kelompok masih belum mampu menjelaskan hasil kerja kelompoknya.

Pelaksanaan diskusi kelas terlihat mahasiswa cukup antusias dalam memberi tanggapan terhadap pendapat kelompok lain dan menjawab pertanyaan dari kelompok lain, mahasiswa juga sudah dapat menyebutkan contoh dan non contoh serta mahasiswa mulai menyenangi pembelajaran yang menerapkan pendekatan konstruktivisme dengan bantuan macromedia flash 8. Berdasarkan lembar observasi siklus 1 diketahui keaktifan mahasiswa pada mata kuliah trigonometri yang menerapkan pendekatan konstruktivisme dengan bantuan macromedia flash 8 berada pada kategori cukup dengan jumlah skor 22. Pada siklus 1 ratarata nilai tes 68,05 dan ketuntasan belajar secara klasikal 53,13\%.

Siklus 2 aktivitas mahasiswa sudah lebih baik dalam menjawab pertanyaan dosen dan menanggapi penjelasan dari kelompok lain. Kerja sama antara mahasiswa dalam satu kelompok lebih baik dibandingkan pada siklus 1 karena dosen sudah menegur mahasiswa yang tidak bekerja sama dengan teman satu kelompoknya untuk menyelesaikan tugas yang diberikan dosen. Hal ini bisa diamati saat mahasiswa melakukan presentasi, mahasiswa yang ditunjuk secara acak oleh Dosen sudah dapat mempresentasikan hasil kerja kelompoknya. Ini menunjukkan bahwa setiap anggota kelompok memahami hasil kerja kelompok mereka masing-masing. Mahasiswa sudah bisa manggunakan konsep dasar yang dimiliki untuk menemukan ide atau gagasan baru, terlihat dari hasil kerja LKS, yaitu saat menjelaskan konsep bahwa melalui sebuah segitiga sembarang dan dengan menggunakan rumus segitiga akan didapat rumus jumlah $\sin (\alpha+\beta)$, rumus selisih dari $\sin (\alpha-\beta)$, serta rumus $\cos (\alpha+\beta)$ dan $\cos (\alpha-\beta)$. Begitu juga dengan cara mendapatkan rumus sudut-sudut rangkap, kelompok 1 mempresentasikan hasil kerjanya yakni dengan menggunakan konsep yang telah didapat kelompok IV yaitu rumus jumlah dan selisih dari dua buah sudut akan didapat rumus-rumus sudut rangkap yaitu rumus $\sin 2 \alpha, \cos 2 \alpha$, dan tan $2 \alpha$.yang dibuat dan kemampuan mahasiswa untuk menjelaskan konsep yang mereka temukan. Ini menunjukkan bahwa kemampuan pemahaman konsep mahasiswa sudah cukup baik karena mahasiswa sudah mampu menyatakan ulang suatu konsep dan mampu mengkonstruksikan pengetahuan dasar yang mereka miliki untuk menemukan konsep beru.

Dari diskusi kelas yang dilakukan mahasiswa lebih banyak mendiskusikan tentang proses untuk menemukan suatu rumus. Pada kegiatan evaluasi diakhir pembelajaran mahasiswa cukup antusias mengerjakan soal yang dibuat dengan bantuan macromedia flash 8, karena mahasiswa dapat langsung mengetahui benar atau salahnya jawaban yang dibuat. Contoh lembar evaluasi dapat dilihat pada Gambar 3.2 berikut.

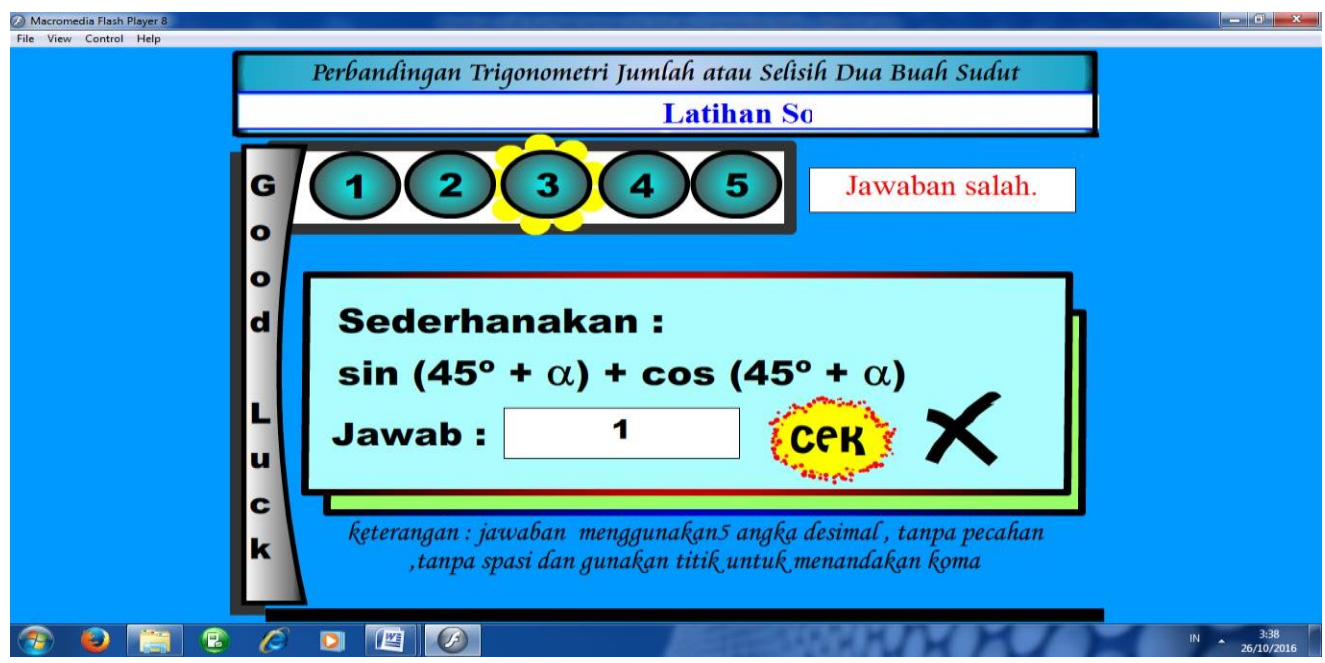

Gambar 3.2. Contoh Lembar Evaluasi dengan Bantuan macromedia flash 8 
Setelah mahasiswa menemukan jawaban mereka dapat langsung mengetahui kebenaran jawaban yang mereka temukan. Pada lembar ini terdapat ikon untuk megecek jawaban serta keterangan dari jawaban yang diberikan. Lembar evaluasi dalam bentuk seperti Gambar 3.2 ini sangat membantu meningkatkan aktivitas mahasiswa dalam menyelesaikan soal-soal, karena mahasiswa sangat antusias untuk segera mengetahui kebenaran dari jawaban yang mereka temukan. Berdasarkan lembar observasi siklus 2 diketahui keaktifan mahasiswa pada mata kuliah trigonometri yang menerapkan pendekatan konstruktivisme dengan bantuan macromedia flash 8 meningkat dari kategori cukup menjadi baik dengan jumlah skor 26. Pada siklus 2 rata-rata nilai tes 71,69. Rata-rata nilai tes pada siklus 2 ini mengalami peningkatan sebesar 3,64 dari siklus 1. Ketuntasan belajar secara klasikal pada siklus 2 adalah 76,36\%, meningkat 23,23\% dari siklus 1 .

Pada siklus 3 tingkat pemahaman konsep mahasiswa sudah baik, terlihat dari kemampuan mahasiswa memberikan contoh dan non contoh dan kemampuan mahasiswa menyatakan ulang suatu konsep. Selain materi mahasiswa juga banyak membahas contoh-contoh aplikasi rumus dalam berbagai bentuk ini menunjukkan kemampuan mahasiswa dalam menyatakan masalah dalam berbagai bentuk representasi matematika. Lembar materi penggunaan daftar logaritma yang menggunakan bantuan macromedia flash 8 dapat dilihat pada Gambar 3.3 berikut :

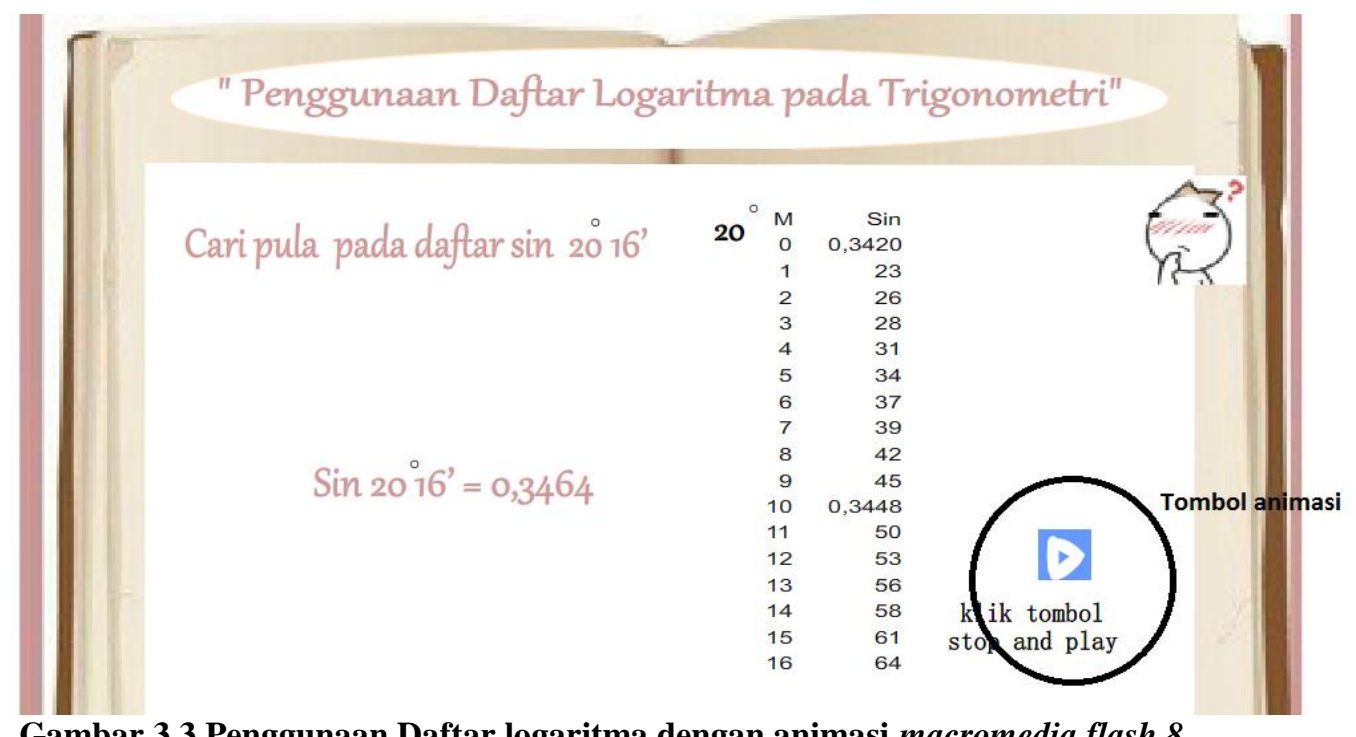

Gambar 3.3 Penggunaan Daftar logaritma dengan animasi macromedia flash 8

Untuk menjelaskan pengggunaan daftar logaritma dosen dapat menggunakna laman ini. Terdapat tombol animasi yang dapat digerakkan dan juga dapat langsung dihentikan. Tombol ini mambantu menjelaskan cara membaca tabel lagaritma. Apabila tombol animasi ini diklik maka tampilan dapat dilihat pada Gambar 3.4 berikut.

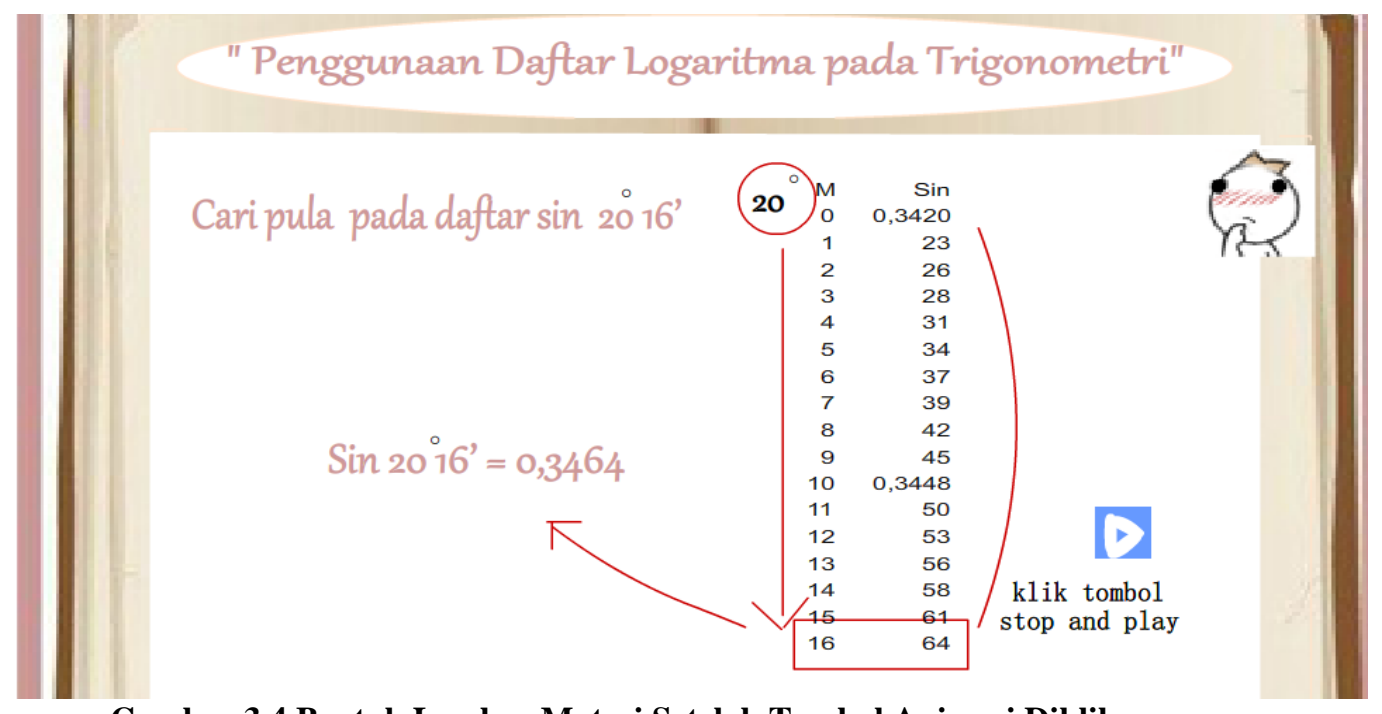

Gambar 3.4 Bentuk Lembar Materi Setelah Tombol Animasi Diklik 
Dengan memperhatikan cara penggunaan daftar logaritma, mahasiswa dapat langsung mempraktekkan dengan cara yang sama seperti yang sudah dijelaskan mada laman materi. Berdasarkan lembar observasi siklus 3 diketahui keaktifan mahasiswa pada mata kuliah trigonometri yang menerapkan pendekatan konstruktivisme dengan bantuan macromedia flash 8 berada pada kategori baik dengan jumlah skor 31. Pada siklus 3 diperoleh rata-rata nilai tes meningkat sebesar 10,76 dari siklus 2 menjadi 82,45 dengan ketuntasan belajar secara klasikal meningkat sebesar 12,73\% dari siklus 2 menjadi 89,09\%. Berdasarkan analisis angket diketahui $95,65 \%$ mahasiswa memberikan respon positif terhadap penerapan pendekatan konstruktivisme dengan bantuan macromedia flash 8 pada mata kuliah trigonometri.

\section{KESIMPULAN}

Berdasarkan hasil penelitian yang dilakukan, diperoleh kesimpulan sebagai berikut:

1. Untuk meningkatkan aktifitas mahasiswa dalam pembelajaran trigonometri dengan pendekatan konstruktivisme yang berbantukan macromedia flash 8 , dilakukan dengna cara:

a. Mahasiswa dibagi ke dalam beberapa kelompok yang heterogen agar mahasiswa melakukan kerjasama dan berdiskusi untuk menyelesaikan masalah.

b. Meminta mahasiswa mengemukakan gagasan terhadap materi yang akan dipelajari.

c. Memberi kesempatan kepada mahasiswa untuk melakukan diskusi kelas sehingga mereka dapat memberi tanggapan dan pertanyaan kepada kelompok lain.

d. Meminta mahasiswa untuk menyiapkan diri untuk mempelajari materi yang akan dibahas pada pertemuan berikutnya di rumah.

2. Penerapan pendekatan konstruktivisme dengan bantuan macromedia flash 8 dapat meningkatkan pemahaman konsep mahasiswa pada mata kuliah trigonometri, yaitu dari nilai rata-rata 68,05 dengan ketuntasan belajar secara klasikal 53,13\% pada siklus 1 dan pada siklus 2 mencapai nilai rata-rata 71,69 dengan ketuntasan belajar secara klasikal 76,36\% serta pada siklus 3 mencapai nilai rata-rata 82,45 dengan ketuntasan belajar secara klasikal 89,09\%. Peningkatan pemahaman konsep trigonometri dengan pendekatan konstruktivisme dengan bantuan macromedia flash 8 dapat dilakukan dengan cara :

a. Meminta mahasiswa untuk menggunakan konsep dasar yang dimiliki, untuk membentuk ide atau gagasan baru.

b. Meminta mahasiswa untuk memberi contoh dan non contoh mengenai materi yang dibahas sehingga diskusi kelas menjadi lebih menarik.

c. Meminta mahasiswa untuk menyatakan ulang suatu konsep dan menyajikan masalah dalam berbagai bentuk representasi matematika.

\section{DAFTAR PUSTAKA}

Afrilianto,M. 2012. Meningkatkan pemehaman konsep dan strategis matematis siswa SMP dengan pendekatan Methaporital thinking. Infiniti. Vol 1. (192-202)

Djamarah, Syaiful Bahri. 2002. Strategi Belajar Mengajar. Jakarta: Rineka Cipta.

Mike, Puteri. Mukhmi. Irwan, 2012, pemahaman konsep matematika pada materi turunan dengan teknik probing, Pendidikan Matematika. Part 2. $(68-72)$

Panen,P. dkk. 2005. Konstruktivisme dalam pembelajaran. Depdiknas. Jakarta

Van de Wall, jhon A. 2008. Matematika sekolah dasar dan menengah pengembangan dan pengajaran. Jilid 1. Jakarta: Airlangga

Widjajanti, Djamilah Bondan. 2011. Mengembangkan kecakapan matematis mahasiswa calon guru matematika melalui strategi perkuliahan kolaboratif berbasis masalah. (proseding Seminar nasional Penelitian, pendidikan dan penerapanMIPA, Fakultas MIPA. UNY. 14 mei 2011. 